\title{
Reading Literacy in Moslem-Majority Countries: Evidence from PISA
}

\author{
Suhendra Yusuf \\ Department of English Language, Universitas Islam Nusantara, Indonesia
}

Received June 25, 2020; Revised July 10, 2020; Accepted August 25, 2020

\section{Cite This Paper in the following Citation Styles}

(a): [1] Suhendra Yusuf, "Reading Literacy in Moslem-Majority Countries: Evidence from PISA," Universal Journal of Educational Research, Vol. 8, No. 9, pp. 4273-4281, 2020. DOI: 10.13189/ujer.2020.080953.

(b): Suhendra Yusuf (2020). Reading Literacy in Moslem-Majority Countries: Evidence from PISA. Universal Journal of Educational Research, 8(9), 4273-4281. DOI: 10.13189/ujer.2020.080953.

Copyright $\odot 2020$ by authors, all rights reserved. Authors agree that this article remains permanently open access under the terms of the Creative Commons Attribution License 4.0 International License

\begin{abstract}
Most Moslem-Majority countries nowadays are still facing a low reading literacy rate of their population, even though the first verse revealed in the Quran speaks of the importance of reading in human life. This paper is aimed at portraying reading literacy in the Moslem world and identifying factors influencing this literacy attainment based on PISA studies. The descriptive-comparative analysis is used to depict the students' reading performance of ten Moslem-Majority countries participating in PISA. The result of this study is that most Moslem-Majority countries lag behind the average of OECD countries. Most of the students were not able to demonstrate the ability of the most fundamental knowledge and skills for the 21 st century. Because reading literacy is the basis for self-development, the Moslem worlds face the tremendous challenge that less than one percent of students achieved high literacy levels; those are the ones who will live on in a global society; while the rest were at the lowest level who shall show solemn setbacks in applying this ability to extend their knowledge and skills. The factors influencing this ability are situated in the national and community contexts that shape home, classroom, and school activities in reading. This situation then affects the instruction and experiences in student's reading. The result of this comparison contributes to the improvement of education systems among the participating countries. This is also a warning that the Moslem worlds have identical educational problems to prepare the next Moslem generation for a better life facing the challenge of globalization.
\end{abstract}

Keywords Reading Literacy, Moslem-Majority Countries, PISA

\section{Introduction}

Even though in its golden age when Islam occupied nearly one-third of the planet and the Moslem authority at that time took the lead of the world in terms of literary tradition, the Moslem today faces serious and severe problems. The unremitting uprisings and social-political instability in the Far-East Moslem-Majority countries are shocking and unbelievable [1]-[4]. The higher illiteracy index that causes poverty and powerlessness in South Asian Moslem-Majority countries is a reality that is inevitable because of a large number of populations [5], [6]. Meanwhile, being the largest Islamic majority country the fourth largest population and the third-largest democracy in the world, Indonesia is almost akin to other Moslem-Majority countries in the sense that the problems related to religiosity and social responsibility, education, health, and prosperity are left unsolved.

The Human Development Index of most Islamic states as an indicator of the success of economic development, health, and education, in the last decade also did not show an increase - even some are declined in comparison with other nations [7]. The indices that rank a hundred more have signaled that the nation's quality is inversely proportional to the quantity. Also, the survey on national competitiveness shows that most Islamic nations will not be able to compete and side by side with other western nations. Various studies on education and literacy levels of our students also suggest that the future of the Islamic nation will not change much because of the level of 
education and low literacy [8].

Another striking occurrence is the result of research that reveals that Moslem-Majority countries do not necessarily live following Islamic precepts wholeheartedly in everyday life [9]-[11]. Using the principles of ideal indicators contained in the teachings of Islam practiced in society, the result of the study put 37 non-Moslem countries all over the world as the first to rank $37^{\text {th }}$ [9]. The highest 'Islamic country' is New Zealand then followed by Luxembourg, Ireland, Iceland, and Finland. This means that non-Moslem-Majority countries are 'more Islamic' than Moslems in carrying out the principles of Islam in daily life. Malaysia (rank 38th in the world) was the first in a group of Islamic majority countries, followed by Kuwait (48), Bahrain (64), Brunei (65), and the United Emirate Arab (66). Indonesia ranked 140 out of 208 countries surveyed, which was under Uganda, Gabon, Jordan, Tunisia, Guyana, Mozambique, Oman, Suriname, Turkey, Maldives, and even under Kazakhstan, Albania, and Kyrgyzstan that in some international education studies, they are always in the bottom lines.

However, the root of the problems lies in the quality of the education system among the Moslem-Majority countries. The results of PISA (Programme for International Student Assessment) launched by the OECD have shown significant differences between OECD countries and developing countries of the Moslem world [12]-[14]. PISA is aimed at examining periodically the ability of students age 15 years (Grade 9 Junior and/or Grade 10 Senior High School) in reading, mathematics, and scientific literacy within a common internationally agreed framework [15]. This study has been conducted several times in 2000, 2003, 2006, and 2009. Like the first PISA in 2000, PISA 2009 also focused on reading literacy; however, the reading framework has been updated to include electronic reading texts [16]-[20]. Ten out of the 65 countries that participated in this survey are Moslem-majority countries. The worldwide survey which focuses on young people's ability to use their knowledge and skills (in reading, mathematics, and science) to meet real-life challenges has successfully portrayed the discrepancy among countries in preparing the future of their students [21]-[23]. This highlights not only differences in the student's performance patterns but also identifies features common to high-performing students, schools and education systems, which can be done by connecting data on learning outcomes with student data and other factors related to learning inside and outside of school. That is why this study is undoubtedly considered as 'a mirror for the future.

The main reasons for countries to participate in international assessments, like us, are to get descriptions, benchmarking, monitoring the quality of education, understanding observed differences, and cross-national research on student achievement [24], [25]. The decision to participate in international assessments was usually made by the National Education Research and Development Body and the main study was implemented by the Center of National Education Assessment, the Ministry of Education. Experts from higher institutions were involved in the preparation, implementation, monitoring, and evaluation of the program.

PISA provides an overview of the following assessment results: (1) indicators of the basic profile of student reading literacy, namely, the students' ability to recognize, understand, use, reflect and engage with written texts, (2) indicators of their reading skills with essential demographic, social, economic and educational variables, and (3) trend indicators arise from data collection that shows changes in the level and distribution of results, as well as the relationship between variables and background results between schools [26]. The data collected in PISA comprises of three parts, namely (1) the students' knowledge to include reading literacy, mathematical literacy, and scientific literacy, (2) the students' background, and (3) school background [12], [22], [27]. Furthermore, this international assessment is expected to enrich the picture of national educational achievements by giving contextual factors from PISA data. The government can show at least three things: firstly, the development of educational outcomes so that equity and equality in the distribution of learning opportunities can be done; secondly, setting policy targets by setting measurable educational goals; and thirdly, mapping to overcome their relative strengths and weaknesses in monitoring and evaluation the progress of the education sector [16], [18], [28].

\section{Literacy: Some Notions}

There are many definitions of literacy, some definitions concern with the skills needed by individuals to work, education, social interaction, and the context of everyday life [29]-[31]. Other definitions focus more on social aspects; including literacy for certain contexts and that empower certain communities that challenge the status quo. How this literacy is defined can certainly influence the types of policies developed and the practice of language teaching and learning [32], [33] [33]. However, in the last two centuries, the notion of literacy has developed. The meaning of literacy as the ability to read and write is still imperative, even though it has also broadened its meaning to include digital technology that has gradually attracted attention on media literacy in family lives and schools [34].

Some researchers state that literacy does not have a single definition and its meaning has changed from time to time from the decoding of written information into a more complex set of skills and understandings. Even the UN also acknowledges a shift in this thinking. In the 1950s, the United Nations Educational, Scientific, and Cultural Organization (UNESCO) stated that a person was declared to have functional literacy if he obtained the knowledge 
and skills in reading and writing that enabled him to engage effectively in all community activities [35], [36]. However, fifty years later, at the official launch of the United Nations Declaration of Literacy in 2003-2012, the UN spokesman acknowledged there was a shift in the definition of a new literacy that was more diverse, multi-dimensional, and studied in different ways [37]. The challenge of global life in this century has compelled our students to obtain basic skills in reading, mathematics, and science as the minimum basic skills so that they can survive in the life of an increasingly complex and competitive world. In the history of mankind, the ability of this basic truth has been taught since the first century through what is called the Artes Liberales curriculum which stated that human capacity can only be developed proportionally if language, mathematics, and science are administered and educated in an integrated way.

The world community then sets a standardized assessment to determine the level of literacy in language, particularly reading literacy, mathematics, and science. The world's three major studies, the PIRLS, PISA, and TIMSS are internationally renowned as benchmarking instruments of the quality of world basic education today [12], [38], [39]. Even though they are not the only reference in the assessment of the quality of education, many countries have used the results of this study as the bases for planning the development of education in their country. PISA itself defines reading literacy as "understanding, using, and reflecting on written texts to achieve one's goals, to develop one's knowledge and potential, and to participate in society" [12], [18].

Literacy is still narrowly defined as the ability to read and write but it is now associated with habituation in reading and appreciating works of literature [40], [41]. However, it is related to thinking skills and lifelong learning to survive in the social and cultural environment. Moreover, literacy can be viewed from three perspectives, namely from linguistic, cognitive, and sociocultural viewpoints [42]-[44]. In the context of language education, he maintains that literacy can be defined as the practice of using socially, historically, and culturally created languages to generate and interpret meanings through texts [41]. This definition requires an understanding of the relationship between textual conventions and the context of their use and the ability to reflect critically on the relationship between text and context.

Accordingly, this capability is divided into three basic skills. First, the ability to read a text (or prose literacy), for example, the ability to understand different opinions in an editorial, appreciate the message in a short story, or comprehend instruction in electronic goods manual; second, the ability to read a document (document literacy), for example, the ability to fill out registration forms, job application forms, or income and taxation forms, or to understand important documents in their daily work; and third, the ability to perform calculations by using the math symbol (quantitative literacy), for example, the ability to pay electricity bills, to calculate the payment, and to deposit their money or credit cards, or estimate bank interests [32].

The determinant factors influencing the student's reading achievement and their behaviors and attitudes are the national and community contexts, which influence home, classroom, and school activities in reading [38], [39], [45], [46]. The whole situation will then affect the instruction and experiences in students' reading. Accordingly, socio-cultural, political, and economic factors are very influential on the environment for the development of children's literacy in a country. It was said that the success of a country in educating its children is very dependent on the state's emphasis on literacy goals, available resources, and effective programs, which can encourage improving reading achievement.

Besides, the national state language-use in a country can also influence the challenges and teaching practices in teaching children to read. Some countries only use one language as their instrument of social interaction, but other countries have historical roots in two or more languages and form multilingual and multicultural societies. As a result, in some countries, decisions about the language of instruction become difficult. Besides, the great attention given by a country to literacy activities will affect the commitment of time and resources that are richer in the community's reading activities [39]. Outside of school, parents and the community can encourage a richer environment that respects reading in everyday life.

Literacy is a contested concept and the process for obtaining literacy is a complex and complicated process [47]. However, the manifestation of difficulties in attaining literacy helps us to understand that the acquisition of literacy is far more intricate than if no difficulties existed. Literacy is not simply only about reading and writing but also about the relationship between text and its reader, between students and teachers, between classroom and community, and among all those things in local, national, and transnational sites [48]. Defining the word "literate" today should go beyond reading and writing skills; it has to involve digital technology to produce various types of texts in critical and creative ways. Digital Literacy ranked among the top five hot topics at both the community and country levels [49], [50]. It means that it also includes the use of numerous media in its literacy development [51]. A student who is unfamiliar with the technology is also proved to have no significant improvement with reading skills [52].

Organization for Economic Co-operation and Development summarizes this idea of literacy by stating that literacy learning in schools and the application of knowledge in everyday life is highly dependent on acquiring broader concepts and skills [12], [16]. In reading literacy, students now must possess the ability to develop interpretations of reading material, to reflect and evaluate 
the content and quality of texts.

In response to the rate of literacy achievement in several countries, constraints that influencing the low achievement in literacy assessment, namely in the input and process of education [53]. The constraints of educational input cover the insufficiency of educators and educational staff; unavailability of learning facilities or inefficient use of the facilities; and inadequacy of education costs, while the constraints of educational process comprise of the heavily loaded contents and teacher's instructional method. The constriction of this education process will then cause ineffectiveness in instructional practice. Besides, with analysis of Covariance Structure with latent variables, known as Structural Equation modeling mentioned several variables affecting directly on reading literacy achievement [38], [45], [54]. These factors among others are the students' self-efficacy, reading homework, and high reading, then followed by teaching method, reading frequency at home, and after reading activities. Self-efficacy is the belief that students can take action or succeed in certain situations, in this case being able to read comprehensively [55]. People with high self-efficacy are more likely to view difficult tasks as something that must be mastered because he is very confident with their abilities and does not try to avoid the tasks given to him [56]-[58]. Besides, parent education, which affects students' attitude and self-efficacy, is one of the factors influencing indirectly on the students' achievement. Other factors are the school economy status and teaching method.

\section{Methods}

This paper discusses the results of PISA and identifies determinant factors influencing the students' performance in reading literacy in Moslem-Majority countries. The data of students' achievement is identified, compared, and analyzed. The analysis is used to portray the students' performance and the contextual determinant factors influencing the students' achievement are also identified and analyzed.

The data used in this paper are secondary data obtained from the OECD report, entitled PISA 2009 Results: What Students Know and Can Do [15], [59]. Student Performance in Reading, Mathematics, and Science, the data are selected and compared just focusing on ten Moslem-Majority countries involved, namely Albania, Azerbaijan, Dubai (UAE), Indonesia, Jordan, Kazakhstan, Kyrgyzstan, Qatar, Tunisia, and Turkey. The reason why only ten countries are chosen as the sample of this study is simply that only these countries participate in the 2009 PISA. Besides, these countries also represent several regions: Europe (Albania, Turkey), Africa (Tunisia), Far-East (UAE, Jordan, Qatar), West Asia (Azerbaijan, Kazakhstan, Kyrgyzstan), and South-East Asia (Indonesia).

Descriptive analysis is used to get an overview of the students' achievement in each country and the determinant factors affecting this attainment.

\section{Result and Discussion}

The overall average scores of all Moslem-Majority countries in Reading (R), Mathematics (M), and Science (S) literary are $\mathrm{R}=395.7, \mathrm{M}=393.9$, and $\mathrm{S}=399.2$, as compared to OECD's average which are 493, 496, and 501 respectively. In reading literacy, the students from Turkey, Dubai, Jordan, Tunisia, and Indonesia are above the average score. Among the Moslem-Majority countries, the students from Turkey have gained the highest score (464), followed by Dubai (UAE, 459), Jordan (405), Tunisia (404), and Indonesia (402). Meanwhile, the students from Kazakhstan (390), Albania (385), Qatar (372), Azerbaijan (362), and Kyrgyzstan (314) are below the average score (395.7), as portrayed in the following Figure 1. 


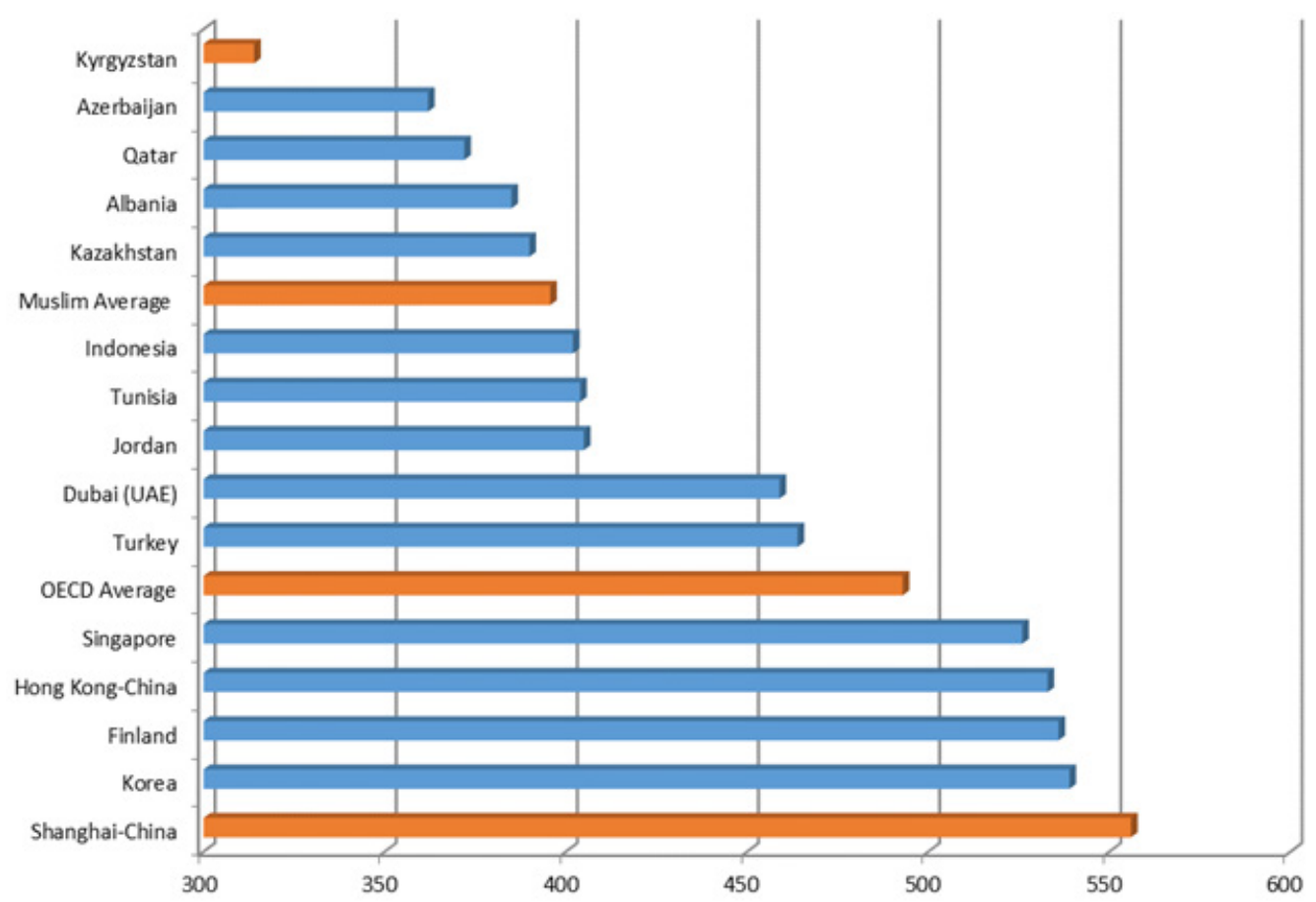

Figure 1. Achievements in Reading Literacy, Moslem-Majority countries, and Five Top Achievers

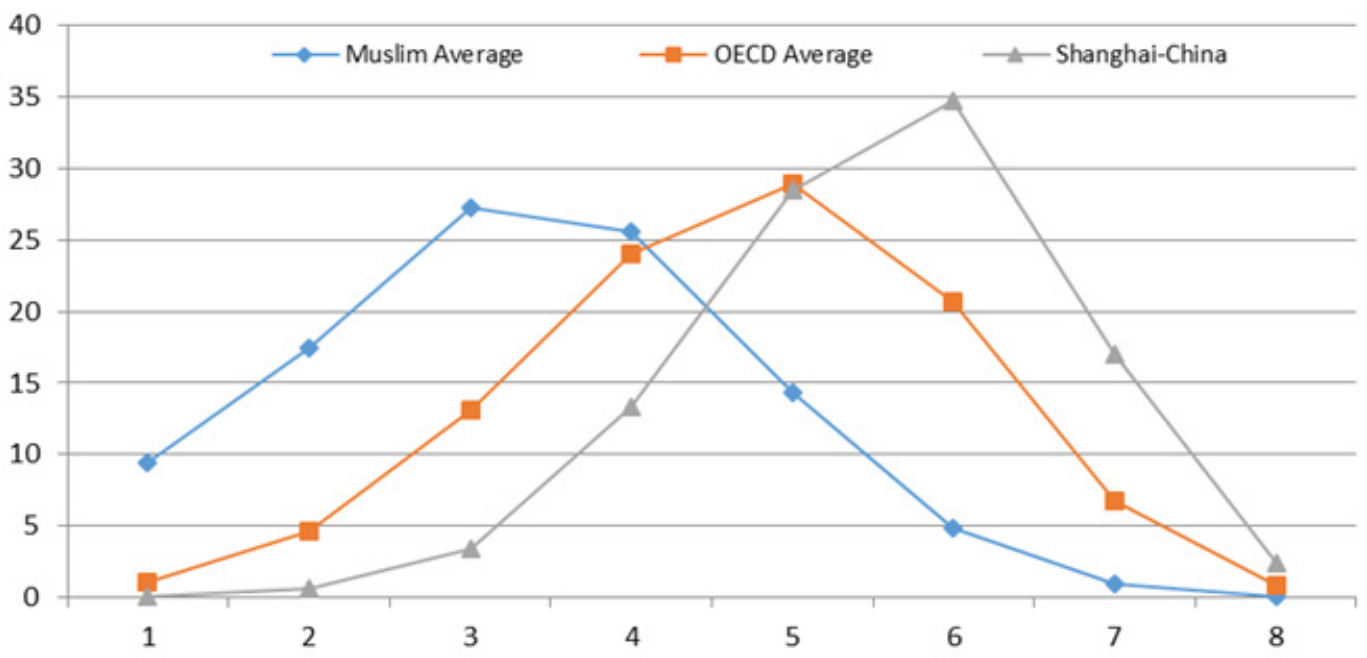

Figure 2. Achievements in Lower to Higher Levels of Literacy

The gap between two means which is almost 100 points has shown that the students in the Moslem-Majority countries are still lagging behind the students of the rest of the world. Compared to the top scorer of Shanghai-China, the gap is so wide with more than 200 points in Math and 150 in reading literacy.

The accomplishment of Moslem students is mostly in low order thinking ability (level 1 to 3 ) compared to higher-order thinking skills, as associated with OECD average and Shanghai-China students. The Figure below shows that the peak of the students' achievement in the Moslem world is in level 3, while the OECD students are in level 5, and the Shanghai-China students are in level 6 . The data show that the percentage of Moslem students who can reach the highest level is only $0.07 \%$, in contrast to OECD $(0.8 \%)$, Shanghai-China $(2.4 \%)$, with the highest percentage is reached by the students from Singapore $(2.6 \%)$. These students are presumably representatives of world-class achievers (see Figure 2).

Very interesting to report here is that the Moslem students are better at answering questions with higher-order thinking skills. The data in Table 1 show that the average score of students in lower skills (in this case the ability to access and retrieve information) is the lowest (390.2), compared to the highest skills (to reflect and evaluate texts, 394.2). Meanwhile, the ability to integrate and interpret the reading text is the best skills that the students have. This is actually 'against' the common law: 
the questions related to the ability to access and retrieve information is much easier than to reflect and evaluate, as also seen from the OECD average score which is 495 (accessing and retrieving information), 493 (integrating and interpreting texts), and 494 (reflecting and evaluating texts). This phenomenon reveals the fact that Moslem students need more challenging tasks to do in day-to-day school activities. Also, it can be assumed that teaching and learning to read in Moslem-Majority countries have lower quality than countries with non-Moslem-Majority populations.

Table 1. Average Scores in Reading sub-Skills

\begin{tabular}{|c|c|c|c|}
\hline Countries & $\begin{array}{c}\text { Accessing } \\
\text { and } \\
\text { retrieving } \\
\text { information }\end{array}$ & $\begin{array}{c}\text { Integrating } \\
\text { and } \\
\text { interpreting } \\
\text { texts }\end{array}$ & $\begin{array}{c}\text { Reflecting } \\
\text { and } \\
\text { evaluating } \\
\text { texts }\end{array}$ \\
\hline Kyrgyzstan & 299 & 327 & 300 \\
\hline Azerbaijan & 361 & 373 & 335 \\
\hline Kazakhstan & 397 & 397 & 373 \\
\hline Albania & 380 & 393 & 376 \\
\hline Qatar & 354 & 379 & 376 \\
\hline Moslem Average & 390.2 & 398.5 & 394.2 \\
\hline Jordan & 394 & 410 & 407 \\
\hline Indonesia & 399 & 397 & 409 \\
\hline Tunisia & 393 & 393 & 427 \\
\hline Dubai (UAE) & 458 & 457 & 466 \\
\hline Turkey & 467 & 459 & 473 \\
\hline OECD Average & 495 & 493 & 494 \\
\hline
\end{tabular}

As the reading texts are divided into continuous texts and non-continuous texts, the Moslem students are better in reading continuous texts (400.4) rather than non-continuous texts (384.2). This indicates that the students are more accustomed to reading long texts (short stories, fiction, and novel) than non-continuous ones (booklets, graphs, tables). The fact can be interpreted that the students have already had good reading habits and are also familiar with other reading activities related to searching quick information from non-continuous passages. However, they still need more both quantity and quality reading activities to extend their reading experiences.

Despite the continuous improvement in most fields, young people in the Moslem world face tremendous problems with their life-skills. The results of PISA have shown that the Moslem schools are not able to prepare their students for a Digital-Age world. In this study, the students rank lower than all participating countries in reading literacy with an average score of 395.7, far behind the five top achievers of Shanghai-China, Korea, Finland, Hong Kong, and Singapore.

This study has described the achievements of students from Moslem countries, which are still very low compared to students from other participating countries. In this case, students in countries with Moslem populations are not ready to compete with students from other countries that will cause the future of students in Moslem countries to be questioned. Governments in Moslem countries must carry out better education reforms to prepare the future of their children so they can compete internationally.

The study shows that most Moslem-Majority countries lag behind the average of OECD countries. Most of the students were not able to demonstrate the ability of the most fundamental knowledge and skills for the 21st century. Because reading literacy is the basis for self-development, the Moslem worlds face an enormous challenge that less than one percent of students achieve higher literacy rate; those are the ones who will live on in a global society; the rest are at the lowest level who shall show solemn setbacks in applying this ability to extend their knowledge and skills.

The result of these studies is a warning that the Moslem worlds have identical educational problems to solve to prepare the next Moslem generation for a better life facing the challenge of globalization.

The students in Moslem countries face major challenges because only a small number of these students can achieve a high reading literacy level. Those who are at a high level of literacy are expected to survive in the knowledge and competition community at the global level. While on one extreme side, most students were unable to demonstrate the most basic skills and knowledge tested in PISA. Students in this group certainly can read, but they show serious difficulties in using their reading knowledge for a wider life.

Several factors have an impact on this low achievement of the students' reading ability, which then can be divided into textual and non-textual factors.

From textual factors, it seems that the selection of textual elements and sentences tested in PISA are still seen as difficult, especially for a group of students who have insufficient reading exposures. This is presumably because the students are not accustomed to the students in learning to read that demands the ability to explore the elements of the text. The text structures of narrative and descriptive text types are also poorly understood. It seems that the students are not trained to understand the parts of the text structure so that students can interpret and assess the content of the text. The students must have the ability to recognize the elements of language in the text and structure of the text.

The determinant non-textual factors influencing this low performance identified among others are students' self-efficacy, reading homework and high reading, reading teaching method, reading frequency at home, and after reading activities. Besides, the social-economic condition as can be seen from the Economic Social and Cultural Index (ESCS Index), learning resources at home and school, teacher's education, and students' learning strategy are also important determinant factors [60].

Among the participating countries, most 
Moslem-Majority countries have a lower ESCS index compared to Turkey, Dubai UAE, and Qatar. This may result in a condition where the economic and social system of the country does not fully support the educational system.

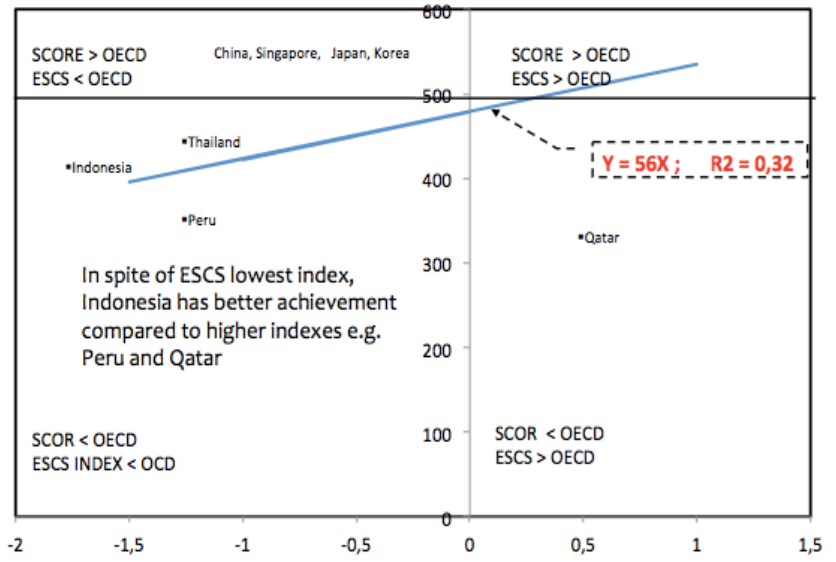

Figure 3. ESCS Index Comparison

However, this weak support did not result in the lowest students' achievement [61], [62]. Some countries having higher ECSC indexes have even lower achievement, e.g., Indonesia has the lowest index (1.60) than Qatar (0.40), yet the Indonesian students' average scores (402) are much better than Qatar (372) as seen in Figure 3.

In detail, the study reported that a parent's educational background and occupation, learning resources at home, especially books and computer availability will influence reading performance. Besides, the language used at home and home location also affects reading literacy attainment and it becomes the most important factor shaping language development and learning among all children. Literature-based education has powerful effects on reading and life-long learning, while access to high-interest books and reading material fosters reading engagement and extensive reading [63], [64].

\section{Conclusions}

Reading ability is the basis for self-development and the students face a significant challenge: less than one percent of students achieve higher literacy rate: those are the ones who will survive in a global society; meanwhile most of the students in the Moslem-Majority countries are at the lower level, those who are not able to demonstrate the most essential competence in reading and show serious difficulties in implementing this ability to extend knowledge and skills. The fact that the Moslem students are better at answering questions with higher-order thinking skills reveals that Moslem students need more challenging tasks to do in day-to-day school activities. Consequently, teaching and learning reading in Moslem-Majority countries has to be more demanding with various tasks so that the students have a better practice.

Other information that Moslem students are better in reading continuous texts rather than non-continuous texts is a sign that the students are more accustomed to reading long texts. It can be deduced that the students have already had good reading ability; however, they still need more both quantity and quality reading activities to extend their reading experiences. The determinant factors influencing the student's reading performance and behaviors are the national and community contexts that influence home, classroom, and school activities in reading. This situation then affects the instruction and experiences in students' reading. In detail, the students' self-efficacy, reading homework, and high reading, then followed by teaching method, reading frequency at home, and after reading activities affect the students' achievement. The study also reported that parent's educational background and occupation, learning resources at home, especially books and computer availability have a significant influence on reading performance, as well as the language used at home and home location. Meanwhile, the quality of school education resources and school size have also an effect on students' performance as well as the availability of certified teachers and full-time teachers, the students' engagement in reading, and their learning strategies.

The results of this study have reminded us in Moslem-majority countries that new rules are needed in the education system in most Muslim-majority countries to prepare their students for the challenges of globalization.

\section{REFERENCES}

[1] S. Karmani, "TESOL in a Time of Terror: Toward an Islamic Perspective on Applied Linguistics," TESOL Q., 2005, doi: $10.2307 / 3588534$.

[2] H. ben H. Salem, “Anabaptized 'moderate': 'moderate Islamists,' American think tanks, and the roadmap to 'the Jasmine Revolution' and 'the Arab Spring'," Int. J. Humanit. Cult. Stud., 2016.

[3] S. E. Krauss, "Towards enhancing youth participation in muslim-majority countries: The case of youth-adult partnership in Malaysia," Pertanika J. Soc. Sci. Humanit., 2018.

[4] P. Bunk, "POST-ISLAMISM AND ART CINEMA IN INDONESIA: QUESTIONING THE FREEDOM AFTER REVOLUTION IN MUSLIM MAJORITY COUNTRIES," PEOPLE Int. J. Soc. Sci., 2019, doi: 10.20319/pijss.2019.43.11981218.

[5] N. J. Davis and R. V. Robinson, "The Egalitarian Face of Islamic Orthodoxy: Support for Islamic Law and Economic Justice in Seven Muslim-Majority Nations," Am. Sociol. Rev., 2006, doi: 10.1177/000312240607100201.

[6] S. Hasan, The Muslim World in the 21st century: Space, power, and human development. 2012. 
[7] A. S. Usman and R. Tasmin, "The Role of Islamic Micro-Finance in Enhancing Human Development in Muslim Countries," J. Islam. Financ., 2016, doi: $10.12816 / 0027652$.

[8] M. B. Anto, "Introducing an Islamic Human Development Index (I-HDI) to Measure Development in OIC Countries," Islam. Econ. Stud., vol. 130, no. 542, pp. 1-54, 2011.

[9] S. S. Rehman and H. Askari, "How islamic are islamic countries?," Glob. Econ. J., 2010, doi: 10.2202/1524-5861.1614.

[10] A. El Younssi, "Maajid Nawaz, Irshad Manji, and the call for a Muslim reformation," Polit. Relig. Ideol., 2018, doi: 10.1080/21567689.2018.1524327.

[11] R. Meijer, "The political, politics, and political citizenship in modern Islam," in The Middle East in Transition: The Centrality of Citizenship, 2018.

[12] OECD, "PISA 2018 insights and interpretations," OECD Publ., 2019.

[13] T. N. Hopfenbeck, J. Lenkeit, Y. El Masri, K. Cantrell, J. Ryan, and J. A. Baird, "Lessons Learned from PISA: A Systematic Review of Peer-Reviewed Articles on the Programme for International Student Assessment," Scand. J. Educ. Res., 2018, doi: 10.1080/00313831.2016.1258726.

[14] E. R. Davis, R. Wilson, and J. R. Evans, "Media neglect of Indigenous student performance in the Programme for International Student Assessment (PISA) 2001-2015," Aust. J. Indig. Educ., 2019, doi: 10.1017/jie.2019.4.

[15] Organisation for Economic Co-operation and Development, "PISA 2009 Results: What Students Know and Can Do: Student Performance in Reading, Mathematics and Science (Volume 1)," 2010.

[16] Organisation for Economic Co-operation and Development-OECD, "PISA 2009 Results: Executive Summary," Executive Summary. 2010.

[17] H. L. Fleischman, P. J. Hopstock, M. P. Pelczar, and B. E. Shelley, "Highlights From PISA 2009: Highlights From PISA 2009 :," Natl. Cent. Educ. Stat., 2010.

[18] OCDE, Pisa 2009. 2010.

[19] J. Baumert et al., PISA 2000: Basiskompetenzen von Schülerinnen und Schülern im internationalen Vergleich. 2001.

[20] P. Stanat et al., PISA 2000: Die Studie im Überblick. Grundlagen, Methoden und Ergebnisse. 2002.

[21] R. Turner and R. J. Adams, "The programme for international student assessment: An overview," J. Appl. Meas., 2007.

[22] S. Sellar and B. Lingard, "The OECD and the expansion of PISA: New global modes of governance in education," $\mathrm{Br}$. Educ. Res. J., 2014, doi: 10.1002/berj.3120.

[23] T. D. Sadler and D. L. Zeidler, "Scientific literacy, PISA, and socioscientific discourse: Assessment for progressive aims of science education," in Journal of Research in Science Teaching, 2009, doi: 10.1002/tea.20327.

[24] V. Lee, C. Franco, and A. Albernaz, "Quality and equality in brazilian secondary schools: a multilevel cross-national school effects study," Annu. Meet. Am. Educ. Res. Assoc., 2004.

[25] V. Reddy, “Cross-national achievement studies: Learning from South Africa's participation in the Trends in International Mathematics and Science Study (TIMSS)," in Compare, 2005, doi: 10.1080/03057920500033571.

[26] M. I. Tsvetkova, "The shadows of reading: Reasons for the bad results of bulgarians in PISA studies," Eur. J. Contemp. Educ., 2016, doi: 10.13187/ejced.2016.17.368.

[27] K. Stacey, "The PISA View of Mathematical Literacy in Indonesia," J. Math. Educ., vol. 2, no. 2, pp. 95-126, 2011.

[28] Organisation for Economic Co-operation and Development, PISA 2009 at a Glance. 2010.

[29] L. Rai, "Exploring literacy in Social Work Education: A social practices approach to student writing," Soc. Work Educ., 2004, doi: 10.1080/0261547042000209170.

[30] B. Hurst, R. Wallace, and S. B. Nixon, "The impact of social interaction on student learning," Read. Horizons, 2013.

[31] C. E. Snow, "Families as social contexts for literacy development," New Dir. Child Adolesc. Dev., 1993, doi: $10.1002 / \mathrm{cd} .23219936103$

[32] H. R. Schugar and M. J. Dreher, "U. S. fourth graders' informational text comprehension: Indicators from NAEP," Int. Electron. J. Elem. Educ., 2017.

[33] G. Shamshayooadeh, "Cultural Literacy in the New Millennium: Revisiting E.D. Hirsch,” Int. J. Humanit. Soc. Sci., 2011.

[34] G. Cappello, "Literacy, media literacy and social change. Where do we go from now?," Ital. J. Sociol. Educ., 2017, doi: 10.14658/pupj-ijse-2017-1-3.

[35] B. V Street, A. Rogers, and D. Baker, "Adult Teachers As Researchers: Ethnographic Approaches To Numeracy and Literacy As Social Practices in South Asia," Convergence, 2006.

[36] B. Street, "What's 'new' in New Literacy Studies?: Critical approaches to literacy in theory and practice," Curr. Issues Comp. Educ., 2003, doi: 10.1016/j.socscimed.2011.02.026.

[37] M. Lonsdale and D. McCurry, Literacy in the New Millennium. National Centre for Vocational Education Research Ltd, 2004.

[38] I. V. S. Mullis, M. O. Martin, P. Foy, and K. T. Drucker, PIRLS 2011 International Results in Reading. 2012.

[39] I. V. S. Mullis, M. O. Martin, P. Foy, and M. Hooper, TIMSS 2015 International Results in Mathematics. New York: TIMSS \& PIRLS, 2015.

[40] A. Paran, "Literacy and Language Teaching," ELT J., 2003, doi: 10.1093/elt/57.1.79.

[41] R. Kern, "Literacy and Language Teaching." Oxford University Press, 2000.

[42] D. Peplow, J. Swann, P. Trimarco, and S. Whiteley, The discourse of reading groups: Integrating cognitive and sociocultural perspectives. 2016.

[43] E. Ferrer and K. Staley, "Designing an EFL Reading 
Program to Promote Literacy Skills, Critical Thinking, and Creativity," CATESOL J., 2016.

[44] K. H. Perry, "What is literacy? -- A critical overview of sociocultural perspectives.," J. Lang. Lit. Educ., 2012, doi: 10.1017/CBO9781107415324.004.

[45] I. V. S. Mullis, M. O. Martin, and M. Sainsbury, PIRLS 2016 Assessment framework. 2015.

[46] I. V. . Mullis, M. O. Martin, P. Foy, and M. Hooper, Timss. Boston: IEA, 2018.

[47] F. Fletcher-Campbell, J. Soler, and G. Reid, "Approaching Difficulties in Literacy Development: Assessment, Pedagogy and Programmes," Approaching Difficulties Lit. Dev. Assess. Pedagog. Program., 2009.

[48] B. Norton, "Identity, literacy, and English language teaching," Iran. J. Lang. Teach. Res., 2013, doi: 10.18806/tesl.v28i1.1057.

[49] J. Cassidy, S. Grote-Garcia, E. Ortlieb, and D. J. Loveless, "What's Hot in Literacy for 2017: Topics Garnering Attention in 2017," Lit. Res. Instr., 2017, doi: 10.1080/19388071.2017.1339544.

[50] National Literacy Trust, "What's Hot, What's Not 2009: What Experts Say about Literacy Issues," Natl. Lit. Trust, 2009.

[51] M. Fantin, "Perspectives on Media Literacy, Digital Literacy and Information Literacy," Int. J. Digit. Lit. Digit. Competence, 2011, doi: 10.4018/jdldc.2010100102.

[52] L. C. C. Fox, "Effects of Technology on Literacy Skills and Motivation to Read and Write," Educ. Hum. Dev. Master's Theses, vol. 522, 2014.

[53] B. Hayat and S. Yusuf, Benchmark internasional mutu pendidikan. Jakarta: Bumi Aksara, 2010.

[54] A. Watts, "International surveys : PISA, TIMSS , PIRLS," Cambridge Int. Exam., 2015.

[55] N. A. N. Y. Boakye, “The relationship between self-efficacy and reading proficiency of first-year students: An exploratory study," Read. Writ., 2015, doi: 10.4102/rw.v6il.52.

[56] A. Bandura, "Guide for constructing self-efficacy scales," Self-efficacy beliefs Adolesc., 2006, doi: 10.1017/CBO9781107415324.004.

[57] A. Bandura, W. H. Freeman, and R. Lightsey, "Self-Efficacy: The Exercise of Control," J. Cogn. Psychother., 1999, doi: 10.1891/0889-8391.13.2.158.

[58] A. Bandura, "Self-efficacy: Toward a unifying theory of behavioral change," Psychol. Rev., 1977, doi: 10.1037/0033-295X.84.2.191.

[59] Organisation for Economic Co-operation andDevelopment, "PISA 2009 results: Overcoming social background: Equity in learning opportunities and outcomes (Volume II)," Paris, 2010 .

[60] E. Vázquez Cano, E. López-Meneses, and F. Sirignano, "Incidencia de las variables no controlables directamente por el sistema educativo en el rendimiento del alumnado en competencia lectora en PISA: Análisis comparativo España-Finlandia," Av. en supervisión Educ. Rev. la Asoc. Insp. Educ. España, no. 20, p. 6, 2014.

[61] H. L. Fleischman, P. J. Hopstock, M. P. Pelczar, and B. E. Shelley, "Highlights From PISA 2009: Performance of U.S. 15-Year-Old Students in Reading, Mathematics, and Science Literacy in an International Context," 2010.

[62] S. Ruff and S. Boes, "The Sum of All Fears: The Effects of Math Anxiety on Math Achievement in Fifth Grade Students and the Implications for School Counselors.," Georg. Sch. Couns. Assoc. J., 2014.

[63] L. Krolak, "Teacher and librarian partnerships in literacy education in the 21st century," Int. Rev. Educ., 2019, doi: 10.1007/s11159-019-09763-8.

[64] J. Pihl, K. S. van der Kooij, and T. C. Carlsten, Teacher and Librarian Partnerships in Literacy Education in the 21st Century. 2017. 